\title{
A DEMATEL-TOPSIS-WINGS APPROACH TO THE CLASSIFICATION OF MULTIMARKET INVESTMENT FUNDS
}

\author{
Frederico Silva Valentim Sallum \\ Fuzzy Consultoria, Brazil \\ E-mail: frederico.sallum@gmail.com \\ Luiz Flavio Autran Monteiro Gomes \\ Ibmec/RJ, Brazil \\ E-mail: luiz.gomes@ibmec.edu.br \\ Maria Augusta Soares Machado \\ Ibmec/RJ, Brazil \\ E-mail: maria.machado@ibmec.edu.br
}

Submission: $13 / 04 / 2018$ Accept: 25/04/2018

\section{ABSTRACT}

This paper analyzes the performance of 20 multimarket investment funds in the Brazilian market from May/2015 to April/2017 in order to categorize them into 4 performance levels. The cumulative rate and the funds' volatility are calculated in 2 periods among the total periods studied, in order to generate a mutual degree of influence among the funds of each group. Next, the WINGS method is applied. This method splits each group into 2 subgroups, generating the 4 levels of classification. The use of the methodology classified 5 funds in each subgroup. The data analysis compared the obtained classification with the classification established by the cumulative rate of the funds throughout the entire period and presented 4 ways to prioritize the decision for the funds ranked higher. These 4 ways of prioritizing the decision aim at assisting investors with different points of view.

Keywords: classification of investment funds, DEMATEL method, TOPSIS method, WINGS method 
INDEPENDENT JOURNAL OF MANAGEMENT \& PRODUCTION (IJM\&P)

http://www.ijmp.jor.br

v. 9, n. 4, October - December 2018

ISSN: 2236-269X

DOI: 10.14807/ijmp.v9i4.822

\section{INTRODUCTION}

The great offer of investment funds and other financial products in the Brazilian financial market make the investor inquire which asset better meets his/her profile and future perspectives. Classifying investment funds consists of placing the collected sample in different levels or performance categories in the studied criteria.

A good classification aims at orienting investors and advisers about the assets' behavior with regard to their decisions, analysis and evaluations. One of the ways of obtaining a classification of the many collectively analyzed assets is using multicriteria methods which support the decision. One of the great advantages of using these methods is to analyze a set of alternatives in light of a set of criteria (LONGARAY; ENSSLIN; MACKNESS, 2014). Therefore, a classification made through these methods allows a comparative evaluation of the studied alternatives.

According to Caldeira et al. (2014), the economy's openness in the 90s and the economic stability achieved by the Plano Real were great allies of the development and growth of investment funds industries in Brazil. These authors also state that the first multimarket investment funds emerged in Brazil in the mid-90s and since then they have been presenting a significant growth.

Thus, it is seen that the investment funds are an investment modality that has already been consolidated in the Brazilian market. The offer of this product in the financial market is also significant and, for that reason, many times it may generate a conflict in the decision making process when an investor analyzes a set of funds eligible to his/her investment under the performance of two or more criteria. With this in mind, a classification of these funds worthy of investment may facilitate the decision, since it presents which ones are closest to his/her profile and future perspectives with respect to these assets.

There are other types of investment funds in the Brazilian market besides multimarket investment funds, for example, fixed income funds, currency, international debt and pension (ANBIMA, 2014). Rovai (2015) emphasizes that it is important to know these types of investment funds, because the performance rate is charged according to the funds' performance, it should be known that the fund's performance is linked to the type of fund used for investment. 
INDEPENDENT JOURNAL OF MANAGEMENT \& PRODUCTION (IJM\&P)

http://www.ijmp.jor.br

v. 9, n. 4, October - December 2018

ISSN: 2236-269X

DOI: 10.14807/ijmp.v9i4.822

This author also reinforces that usually fixed income funds have a lower return than the multimarket investment funds. Multimarket investment funds have investment policies attached to many risk factors without necessarily concentrating on a risk factor alone. Because of that, there are multimarket funds that are more conservative than fixed income funds and others more aggressive than investment funds in shares.

Hedge funds are funds that adopt a certain number of investment strategies that cannot be adopted by traditional investment funds without being more or less risky than these ones (INFOMONEY, 2005). Malaquias and Eid (2014) state that funds classified as multimarket use hedge funds strategies utilized in other countries and, with that, Brazilian managers can be found using characteristics similar to these ones.

This paper strives to analyze monthly profitability's of 20 multimarket investment funds in the Brazilian market from May/2015 to April/2017, in order to classify them into 4 performance levels. For this purpose, initially the DEMATEL method is applied, which will split the studied funds into 2 groups: Group A and Group B.

It is necessary for the implementation the DEMATEL method to do the classification of the funds month by month in a decreasing order and through these classifications, the degrees of mutual influence will be established. Thereafter, the WINGS method is applied to each of the groups created previously. However, it is necessary to define the degree of power of each fund in its group and the degree of mutual influence between the members of each group.

The TOPSIS method is applied in order to define the degree of power of each fund in the group they belong to. Moreover, the degree of mutual influence between the members of each group is identified by the calculation of the cumulative rate and the volatility in two periods among the total of periods studied, the last 12 months and the 12 second-to-last months.

After the degrees of power of each fund in its group and the degree of mutual influence among the members of each group are established, the WINGS method is applied in groups A and B. The WINGS method splits group A into two subgroups: Subgroup $A_{1}$ and Subgroup $A_{2}$; and splits Group B into 2 subgroups: Subgroup $B_{1}$ 
INDEPENDENT JOURNAL OF MANAGEMENT \& PRODUCTION (IJM\&P)

http://www.ijmp.jor.br

v. 9, n. 4, October - December 2018

ISSN: 2236-269X

DOI: 10.14807/ijmp.v9i4.822

and Subgroup $B_{2}$. Subgroup $A_{1}, A_{2}, B_{1}$ and $B_{2}$ are the 4 performance levels defined in order to classify the 20 analyzed multimarket investment funds.

\section{BIBLIOGRAPHIC REVIEW}

\subsection{Consulted Studies}

Many scholars have been using different multicriteria analysis methods to evaluate, sort, classify and select investment funds in their studies. That happens because these methods are able to evaluate various investment funds as alternatives in light of their performances in more than one criterion. Since there are many ways to evaluate investment funds through indicators already consecrated in literature, a multicriteria approach is able to analyze a set of investment funds to be studied, considering their performance in the criteria used in the evaluation.

As it has been previously said, there are many indicators outlined in the investment funds' literature. Many of these indicators are used by researchers and market traders to evaluate investment funds. Elton and Gruber (1995) and Haugen (1997) mention as an example the Treynor ratio, the Sharpe ratio, the Jensen's alpha, the Sortino ratio, the Modigliani risk-adjusted performance, among others. However, it is important to highlight that each indicator has its limitation.

Varga (2001) reports the difficulty in applying some performance indicators to Brazilian funds. What occurs is that each return indicator adjusted to risk takes into consideration only one risk measurement (MELO; MACEDO, 2013). In this regard, the use of multicriteria methods in the performance analysis of investment funds allows the evaluation of the set of investment funds to be analyzed, considering the performance of all the indicators seen as relevant by the analyst.

Melo and Macedo (2013) examined the performance of macro multimarket investment funds in Brazil from April/2005 to March/2010. In the research, the Data Envelopment Analysis (DEA) was used. Although it was not part of the multicriteria analysis, it has allowed a joint analysis of various parameters considered relevant to the performance evaluation of an investment fund.

Mesrinejad and Moradi (2015) used the TOPSIS method to classify 20 investment fund offered in Tehran's, capital of Iran, stock exchange. The use of this method allowed the classification of the 20 funds studied according to their 
INDEPENDENT JOURNAL OF MANAGEMENT \& PRODUCTION (IJM\&P)

http://www.ijmp.jor.br

v. 9, n. 4, October - December 2018

ISSN: 2236-269X

DOI: 10.14807/ijmp.v9i4.822

performance in 3 indicators: Sharpe's ratio, Jensen's alpha and Treynor's ratio over 12 months.

Duarte and Medeiros (2016) used the TOPSIS method to select funds of private equity in Brazil in a case in which 11 private equity investment funds are offered in the national financial market. The implementation of the TOPSIS method has allowed the analysis of the 11 offered funds according to the performance of each one in 22 criteria.

As a consequence, the classification and selection of possible investments were possible. Martins (2014) uses the TOPSIS method to evaluate managers, classify investment funds in shares and classify multimarket investment funds. In this piece of work, qualitative and quantitative criteria were used for the classifications. The implementation of the TOPSIS method facilitates the high complexity described in the work involved in the selection of investment funds with criteria, which are many times conflicting and should be analyzed simultaneously.

Gomes, Rangel and Santos (2016) applied the AHP method in order to classify mutual funds for a subsequent selection in light of the criteria that identify the investor's characteristics and aims. This paper seeks to offer diversification in the portfolio of mutual investment funds placing the assets on the investor's profile in the appropriate manner.

The use of the AHP method brought a better comprehension of the problem and the assets' ordination that entailed a portfolio's selection. Mello (2014) used the WINGS and AHP methods to classify the credit risk of 14 sectors in the economy with qualitative and quantitative criteria. This author explains that the use of the WINGS method was made to measure how sectors of economy influence each other in the classification model created.

With a joint implementation of these methods it was possible to obtain a way of classifying economic sectors considering the degree of influence that exists between them as well as its strength inside the Brazilian market.

\subsection{The DEMATEL Method}

The DEMATEL method - Decision Making Trial and Evaluation Laboratory was developed by Gabus and Fontela (1972) in order to analyze a set of 
INDEPENDENT JOURNAL OF MANAGEMENT \& PRODUCTION (IJM\&P)

http://www.ijmp.jor.br

v. 9, n. 4, October - December 2018

ISSN: 2236-269X

DOI: 10.14807/ijmp.v9i4.822

components, alternatives or criteria, able to exert influence one over the other, not always in a reciprocal manner.

The first step to apply the DEMATEL is to build a crossed relationship matrix $A$, expressing the degree of influence that the element $i$ of the matrix line exerts over the element $j$ in the matrix's column, where $a_{i j}$ is the influence that element $i$ exerts over the element $j$. For that, a comparative scale of degrees of influence should be established. For example, in a scale from 0 to 4,0 means no influence, 1 low influence, 2 medium influence, 3 high influence and 4 very high influence. If it is necessary, this scale can be amplified.

The second step is to build the direct relationship matrix $D$, calibrating the previous matrix according to Equations 1 and 2.

$D=A \times S$

where:

$S=\max \left(\begin{array}{c}\max \\ 1 \leq i \leq n\end{array} \sum_{j=1}^{n} a_{i j} \max _{i \leq j \leq n} \sum_{i=1}^{n} a_{i j}\right)^{-1}$

The third step is to build the total relationship matrix $T$ according to Equation

3.

$T=D(I-D)^{-1}$

In the Equation 3, $I$ is the identity matrix and $(I-D)^{-1}$ an inverse matrix. From then on, the sum of each line $r_{i}$ of the matrix $T$ (Equation 4) and sum of each column $c_{i}$ of the matrix $T$ (Equation 5) are calculated.

$$
\begin{aligned}
& r_{i}=\sum_{j=1}^{n} t_{i j} \\
& c_{i}=\sum_{i=1}^{n} t_{i j}
\end{aligned}
$$

The line's sum of each element $r_{i}$ represents the total impact that each element has in the set of analyzed elements. The column's sum of each element $c_{i}$ represents the total impact received by each element in the set of analyzed elements. 
INDEPENDENT JOURNAL OF MANAGEMENT \& PRODUCTION (IJM\&P)

http://www.ijmp.jor.br

v. 9, n. 4, October - December 2018

ISSN: 2236-269X

DOI: 10.14807/ijmp.v9i4.822

The sum $r_{i}+c_{i}$ should also be calculated for each element, which represents the total involvement that each element has in the set of analyzed elements and the difference $r_{i}-c_{i}$, which represents the net effect that each element has in the set of analyzed elements.

DEMATEL classifies the analyzed components into 2 groups: the impacted, which have negative $r_{i}-c_{i}$ and the impactors, which have positive $r_{i}-c_{i}$. This happens because the impactors exert a degree of impact superior to the degree of impact they receive inside the analyzed set. The impacted receive a degree of impact superior to the one the exert over the other component inside the analyzed set.

\subsection{The TOPSIS Method}

The TOPSIS method (Technique for Order Preferences by Similarity to Ideal Solution) was originally proposed by Hwang and Yoon (1981). The main idea is based on the compromised solution concept, which implies having to make a concession to reach an agreement.

In this case, the aim is to choose the closest alternative to the positive ideal solution (optimal solution) and the farthest from the negative ideal solution (inferior solution) (TZENG; HUANG, 2011). Each alternative is evaluated according to each attribute defined by the decision maker. The TOPSIS measures the distance between each alternative and the positive ideal and negative ideal solutions.

The basic elements needed for the implementation of the TOPSIS are: a set of alternatives $A=\left\{a_{k} \mid k=1, \ldots, n\right\}$, where $\mathrm{k}$ is the ordinal number of each alternative and $\mathrm{n}$ is the alternatives' total inside the multicriteria matrix; a set of criteria $C=\left\{c_{j}\right.$ $j=1, \ldots, m\}$, where $j$ is the ordinal number of each criterion and $m$ is the criteria's total inside the multicriteria matrix; $X=\left\{x_{k j} \mid k=1, \ldots, n ; j=1, \ldots, m\right\}$ is a set of performance evaluations of each alternative $k$ according to each criterion $j$; and $W=\left\{w_{j} \mid j=1, \ldots, m\right\}$ is a set of weights given to each criterion according to the decision maker's preferences, with $w_{j}$ being the weight of criterion $j$.

There are two types of criteria: cost or benefit. The benefit criteria indicates that the bigger the value, the more likely it will become an alternative. As for the cost criteria, the opposite is what counts. The positive ideal solution maximizes the benefit criteria and minimizes the cost criteria and the negative ideal solution 
INDEPENDENT JOURNAL OF MANAGEMENT \& PRODUCTION (IJM\&P)

http://www.ijmp.jor.br

v. 9, n. 4, October - December 2018

ISSN: 2236-269X

DOI: 10.14807/ijmp.v9i4.822

maximizes cost criteria and minimizes the benefit criteria. For the negative ideal solution to take place, the opposite happens (HWANG; YOON, 1981).

The first step to implement the TOPSIS method consists of calculating the standardized matrix of the performance evaluations, outlined by $r_{k j}(x)$ (Equation 6), that is, the standardized performance evaluation of alternative $a_{k}$ in the criterion $c_{j}$. Which enables the comparison between attributes of different scales.

$r_{k j}(x)=\frac{x_{k j}}{\sqrt{\sum_{k=1}^{n} x_{k j}^{2}}}, k=1, \ldots, n ; j=1, \ldots, m$

The second step considers the performance evaluation by the weight of each criterion. The result is given by $v_{k j}(x)$ (Equation 7), that is, the result of alternative k's evaluation in the criterion $j$.

$v_{k j}(x)=w_{j} r_{k j}(x), k=1, \ldots, n ; j=1, \ldots, m$

Moreover, the positive ideal solution (PIS) and the negative ideal solution (NIS) must be identified. The PIS $\left(A^{+}\right)$and the NIS $\left(A^{-}\right)$are calculated with the maximum or minimum value of $v_{k j}(X)$ in each criterion (Equation 8 and Equation 10); $v_{j}^{+}(x)$ to measure the PIS and $v_{j}^{-}(x)$ to measure the NIS (Equation 9 and Equation 11) where $J_{1}$ and $J_{2}$ are the benefit and cost criteria, respectively.

$$
\text { PIS }=A^{+}=\left\{v_{1}^{+}(x), v_{2}^{+}(x), \ldots, v_{j}^{+}(x), \ldots, v_{m}^{+}(x)\right\}
$$

where:

$$
\begin{aligned}
& v_{j}^{+}(x)=\left(\max _{k} v_{k j} j \in J_{1} ; \min _{k} v_{k j} j \in J_{2}\right) \\
& N I S=A^{-}=\left\{v_{1}^{-}(x), v_{2}^{-}(x), \ldots, v_{j}^{-}(x), \ldots, v_{m}^{-}(x)\right\}
\end{aligned}
$$

where:

$$
v_{j}^{-}(x)=\left(\min _{k} v_{k j} j \in J_{1} ; \min _{k} v_{k j}, j \in J_{2}\right)
$$

The next step is to calculate the Euclidean distances between $A^{+}$and $A_{k}\left(d_{k}{ }^{+}\right)$ for benefits (Equation 12) and between $A^{-}$and $A_{k}\left(d_{k}^{-}\right)$for costs (Equation 13). 


$$
\begin{aligned}
& d_{k}^{+}=\sqrt{\sum_{j=1}^{m}\left[v_{j}^{+}(x)-v_{k j}(x)\right]^{2}, k=1, \ldots, n} \\
& d_{k}^{-}=\sqrt{\sum_{j=1}^{m}\left[v_{j}^{-}(x)-v_{k j}(x)\right]^{2}, k}=1, \ldots, n
\end{aligned}
$$

The final value generated by the TOPSIS is the calculation of the relative proximity $\xi_{k}$ for each alternative $A_{k}$. Through the value of $\xi_{k}$, there's the alternatives' ordination (Equation 14):

$\xi_{k}=\frac{d_{k}^{-}}{d_{k}^{+}+d_{k}^{-}}$

\subsection{The WINGS Method}

The WINGS method - Weighted Influence Non-linear Gauge System (MICHNIK, 2013) is derived from the method DEMATEL - Decision Making Trial and Evaluation Laboratory (GABUS; FONTELA, 1972). It is use allows the indication of the degree of influence among the variables utilized in a certain multicriteria evaluation context.

From this point of view, the WINGS method emerged with the assumption that the influence among the components of the decision-making system - in this case, alternatives or criteria - is not enough to calculate factors such as impact, receptivity and the variables' involvement; also, which components should be properly studied, considering a variable's strength inside the system. This factor is not used in the DEMATEL method.

The first step to use the WINGS method is to select two or more components to form a system, a set of alternatives or criteria studied. Next, the degree of power that each component possess inside the system should be established in 5 points: (0) no strength; (1) low strength; (2) moderate strength; (3) high strength and (4) very high strength. The degree of influence that each component possesses over the other should also be established in 5 points: (0) no influence; (1) low influence; (2) moderate influence; (3) high influence and (4) very high influence. If appropriate, the scale should extended in order to avoid very approximate readings, given the nature 
INDEPENDENT JOURNAL OF MANAGEMENT \& PRODUCTION (IJM\&P)

http://www.ijmp.jor.br

v. 9, n. 4, October - December 2018

ISSN: 2236-269X

DOI: 10.14807/ijmp.v9i4.822

of the problem studied, the user can extend it (MICHNIK, 2013). The Equation 15 illustrates an example with three components.

$D=\left[\begin{array}{lll}4 & 1 & 4 \\ 3 & 2 & 2 \\ 2 & 3 & 2\end{array}\right]$

In the second step, the matrix $D$ should be calibrated according to Equations 16 and 17 , transforming it into matrix $C$.

$C=\frac{1}{s} D$

where:

$s=\sum_{i=1}^{n} \sum_{j=1}^{n} d_{i j}$

The WINGS method's third step follows the DEMATEL method's steps as of equations 3,4 and 5. Just as in the DEMATEL method, the system of sum and difference $r_{i}+c_{i}$ and $r_{i}-c_{i}$ of each element inside the system should also be calculated. In such calculations, $r_{i}$ represents the total impact that a component has in the system, whereas $c_{i}$ represents the total receptivity (received impact) that an element has inside the system.

The sum $r_{i}+c_{i}$ represents the total involvement that a component has inside the system, because it is the result of the sum of how one component impacts the others and how the others impact it too. The difference $r_{i}-c_{i}$, on the other hand, classifies the system's components as influenced, in case its result is a negative number, or influencing, in case its result is a positive number, since it expresses the difference between the total impact that an element has over the others and the total impact received by the rest.

\section{METHODOLOGY AND IMPLEMENTATION}

The monthly profitability of 20 multimarket investment funds currently in the Brazilian investment funds market from May/2015 to April/2016 will be studied. The software ECONOMÁTICA ${ }^{\circledR}$ was used to obtain the monthly profitability. The funds analyzed are presented in Table 1 as well as the abbreviation of each fund's name to be mentioned throughout this paper. 
Table 1: Multimarket investment funds and abbreviation

\begin{tabular}{|c|c|}
\hline Fund & Abbreviation \\
\hline Apex Equity Hedge Str FI Mult & Apex \\
\hline BB Mult Macro LP Estilo Fc & BB \\
\hline Bradesco H FI Mult Bolsa Americana & Bradesco \\
\hline Brasil Plural Crd Corp FI Mult Cred Priv & Brasil \\
\hline BTG Pactual Explorer FI Mult & BTG \\
\hline Citifirst Cap Prot IX FICFI Mult & Citifirst \\
\hline Fator Portfolio Verde Fiqfi Mult & Fator \\
\hline Growler FICFI Mult & Growler \\
\hline Itau Mult Equity Hedge FICFI & Itaú \\
\hline Manager ARX Extra Fc FI Mult & ARX \\
\hline Maua Macro FICFI Mult & Mauá \\
\hline Modal Tactical FIC de FI Mult & Modal \\
\hline Opportunity Plus FIC de FI Mult & Opp. \\
\hline Safra S\&P FI Mult & Safra \\
\hline Santander FICFI Pb Top Managers Mult & Santander \\
\hline Sicredi - FI Mult Perfil Classico LP & Sicredi \\
\hline Spx Capital Portfolio FIC Mult & SPX \\
\hline Sul America Endurance FI Mult & Sul \\
\hline Vinci Valorem FI Mult & Vinci \\
\hline Xp Long Biased Fc FI Mult & XP \\
\hline
\end{tabular}

This paper seeks to classify multimarket investment funds into 4 performance levels: $A_{1}, A_{2}, B_{1}$ and $B_{2}$. By splitting the funds into 2 groups, $A$ and $B$, and each group into 2 subgroups. With $A^{\prime}$ 's subgroups being: $A_{1}$ and $A_{2}$; and $B$ 's subgroups being: $B_{1}$ and $B_{2}$, according to the performance reached throughout the analyzed period. Initially, the DEMATEL method will be applied, which will split the 20 analyzed funds into 2 groups.

Next, the TOPSIS method is used to establish the degree of power of each alternative inside the group it was designated by the DEMATEL method. This degree of power will be utilized during the implementation of the WINGS method. The TOPSIS' methodology uses the difference between the alternative with the best performance and the others in each criterion and the difference between the alternative with the worst performance and the others in each criterion. Thus, the best fund will be the closest to have achieved the best return in all criteria and the farthest from obtaining the worst performance in all criteria.

The profitability's are analyzed by the TOPSIS method as grades or scores acquired by the funds being studied each month and note as a rate properly speaking, because the difference will be calculated according to Equation 12 and 
INDEPENDENT JOURNAL OF MANAGEMENT \& PRODUCTION (IJM\&P)

http://www.ijmp.jor.br

v. 9, n. 4, October - December 2018

ISSN: 2236-269X

DOI: 10.14807/ijmp.v9i4.822

Equation 13 and not by the calculation commonly used to obtain the difference between to rates (Equation 18). Equation 18 presents the calculation to obtain the difference between rates $i_{1}$ and $i_{2}$.

spread $=\left\{\left[\frac{1+\left(\frac{i_{1}}{100}\right)}{1+\left(\frac{i_{2}}{100}\right)}\right]-1\right\} \times 100$

A degree of power for each alternative is given through the value of the relative proximity of each alternative calculated by the TOPSIS method. After that, the WINGS method should be applied. Besides the degree of power, the degree of influence between alternatives should also be established. For that, 4 other criteria will be analyzed for the alternatives in both groups, which are able to establish a degree of influence between alternatives: each fund's cumulative rate in the last 12 months (May/2016 to April/2017) and in the 12 second-to-last months (May/2015 to April/2016) as well as the volatility in the last 12 months and the volatility in the 12 second-to-last months.

After establishing the degree of influence between the alternatives of each group by the 4 criteria mentioned above, the WINGS method is applied, which will split the alternatives from each group into 2 subgroups based on the degree of power each alternative has inside their group and on the degree of mutual influence in the 4 criteria mentioned above. Tables 2, 3, 4 and 5 present the monthly profitability of the analyzed multimarket investment funds from April/2017 to November/2016, October/2016 to May/2016, April/2016 to November/2015 and October/2015 to May/2015, respectively. 
INDEPENDENT JOURNAL OF MANAGEMENT \& PRODUCTION (IJM\&P)

http://www.ijmp.jor.br

v. 9 , n. 4, October - December 2018

ISSN: 2236-269X

DOI: 10.14807/ijmp.v9i4.822

Table 2: Monthly profitability of the analyzed funds from April/2017 to November/2016

\begin{tabular}{|c|c|c|c|c|c|c|}
\hline Fund & Apr/2017 & Mar/2017 & Feb/2017 & Jan/2017 & Dec/2016 & Nov/2016 \\
\hline Apex & $1.1109 \%$ & $-0.1727 \%$ & $3.2581 \%$ & $2.7341 \%$ & $2.4493 \%$ & $-0.4288 \%$ \\
\hline BB & $1.0145 \%$ & $1.8511 \%$ & $0.4458 \%$ & $1.0627 \%$ & $1.6151 \%$ & $2.6564 \%$ \\
\hline Bradesco & $1.5614 \%$ & $0.8875 \%$ & $4.8499 \%$ & $2.0401 \%$ & $3.0771 \%$ & $4.4245 \%$ \\
\hline Brasil & $0.9209 \%$ & $1.1897 \%$ & $1.0866 \%$ & $1.3086 \%$ & $1.2905 \%$ & $1.1533 \%$ \\
\hline BTG & $0.8766 \%$ & $1.1033 \%$ & $1.0487 \%$ & $1.6049 \%$ & $1.2919 \%$ & $0.7912 \%$ \\
\hline Citifirst & $1.0499 \%$ & $1.5507 \%$ & $1.3497 \%$ & $1.5966 \%$ & $-1.6044 \%$ & $-1.4969 \%$ \\
\hline Fator & $0.4359 \%$ & $1.1122 \%$ & $1.3553 \%$ & $0.1063 \%$ & $3.0705 \%$ & $1.0307 \%$ \\
\hline Growler & $-0.1390 \%$ & $1.8956 \%$ & $0.9669 \%$ & $2.6838 \%$ & $1.9791 \%$ & $1.9784 \%$ \\
\hline Itaú & $1.2625 \%$ & $1.5229 \%$ & $1.1487 \%$ & $2.0377 \%$ & $1.2162 \%$ & $0.8121 \%$ \\
\hline ARX & $1.2751 \%$ & $1.2548 \%$ & $1.8855 \%$ & $4.8000 \%$ & $2.1387 \%$ & $-0.1712 \%$ \\
\hline Mauá & $1.6880 \%$ & $0.1299 \%$ & $3.9582 \%$ & $3.2135 \%$ & $3.4906 \%$ & $0.0442 \%$ \\
\hline Modal & $-0.0137 \%$ & $1.4396 \%$ & $1.9749 \%$ & $2.0911 \%$ & $1.9467 \%$ & $1.4402 \%$ \\
\hline Opp. & $0.0773 \%$ & $0.8808 \%$ & $2.1389 \%$ & $1.1674 \%$ & $3.0377 \%$ & $-0.6781 \%$ \\
\hline Safra & $2.4962 \%$ & $0.5491 \%$ & $2.4288 \%$ & $-1.4371 \%$ & $-1.7932 \%$ & $10.5080 \%$ \\
\hline Santander & $0.5433 \%$ & $0.9845 \%$ & $1.4016 \%$ & $2.1788 \%$ & $2.0631 \%$ & $0.5880 \%$ \\
\hline Sicredi & $0.5875 \%$ & $1.3668 \%$ & $1.2903 \%$ & $1.0262 \%$ & $0.9935 \%$ & $0.9795 \%$ \\
\hline SPX & $-0.1088 \%$ & $1.9355 \%$ & $0.9929 \%$ & $2.7076 \%$ & $2.0044 \%$ & $2.0007 \%$ \\
\hline Sul & $1.0534 \%$ & $1.2607 \%$ & $1.0085 \%$ & $1.4019 \%$ & $1.1272 \%$ & $0.6170 \%$ \\
\hline Vinci & $0.5070 \%$ & $1.5025 \%$ & $1.9677 \%$ & $1.5553 \%$ & $1.4969 \%$ & $0.4907 \%$ \\
\hline XP & $-2.0169 \%$ & $-3.7855 \%$ & $1.5687 \%$ & $7.7109 \%$ & $-0.0758 \%$ & $-3.2819 \%$ \\
\hline
\end{tabular}

Table 3: Monthly profitability of the analyzed funds from October/2016 to May/2016

\begin{tabular}{|c|c|c|c|c|c|c|}
\hline Fund & Oct/2016 & Sep/2016 & Aug/2016 & Jul/2016 & Jun/2016 & May/2016 \\
\hline Apex & $3.5013 \%$ & $0.9580 \%$ & $-0.8403 \%$ & $1.7455 \%$ & $2.1722 \%$ & $1.3398 \%$ \\
\hline BB & $3.1371 \%$ & $5.6330 \%$ & $5.1054 \%$ & $3.8309 \%$ & $1.1117 \%$ & $0.0274 \%$ \\
\hline Bradesco & $-0.8560 \%$ & $0.7388 \%$ & $1.0948 \%$ & $4.6187 \%$ & $0.9931 \%$ & $2.6961 \%$ \\
\hline Brasil & $1.1836 \%$ & $1.3368 \%$ & $1.4740 \%$ & $1.2537 \%$ & $1.3156 \%$ & $1.3229 \%$ \\
\hline BTG & $1.2867 \%$ & $1.7180 \%$ & $1.1182 \%$ & $1.4805 \%$ & $0.4554 \%$ & $0.8733 \%$ \\
\hline Citifirst & $21.9141 \%$ & $-3.4113 \%$ & $6.7695 \%$ & $3.4421 \%$ & $-4.2403 \%$ & $2.1397 \%$ \\
\hline Fator & $1.0890 \%$ & $1.2012 \%$ & $1.6367 \%$ & $1.8186 \%$ & $1.7657 \%$ & $1.5214 \%$ \\
\hline Growler & $2.7767 \%$ & $2.2500 \%$ & $2.4844 \%$ & $0.3518 \%$ & $-0.0785 \%$ & $1.7886 \%$ \\
\hline Itaú & $2.0303 \%$ & $1.5411 \%$ & $1.0850 \%$ & $1.8648 \%$ & $1.6993 \%$ & $0.4353 \%$ \\
\hline ARX & $3.1316 \%$ & $1.5920 \%$ & $1.9183 \%$ & $2.7797 \%$ & $3.3205 \%$ & $-0.5193 \%$ \\
\hline Mauá & $2.6918 \%$ & $2.8527 \%$ & $1.4688 \%$ & $0.6821 \%$ & $0.7164 \%$ & $0.0606 \%$ \\
\hline Modal & $1.1617 \%$ & $1.5628 \%$ & $0.0044 \%$ & $1.2958 \%$ & $2.7902 \%$ & $0.8882 \%$ \\
\hline Opp. & $2.1206 \%$ & $0.2444 \%$ & $0.7709 \%$ & $2.1168 \%$ & $2.5062 \%$ & $2.2909 \%$ \\
\hline Safra & $-3.7600 \%$ & $0.3990 \%$ & $-0.3569 \%$ & $4.9782 \%$ & $-10.8964 \%$ & $7.0104 \%$ \\
\hline Santander & $2.2925 \%$ & $1.5564 \%$ & $0.9761 \%$ & $1.3106 \%$ & $1.2869 \%$ & $1.0818 \%$ \\
\hline Sicredi & $1.1317 \%$ & $1.0506 \%$ & $1.1287 \%$ & $1.1582 \%$ & $1.0542 \%$ & $1.1978 \%$ \\
\hline SPX & $2.7826 \%$ & $2.2143 \%$ & $2.5062 \%$ & $0.3888 \%$ & $0.0113 \%$ & $1.7737 \%$ \\
\hline Sul & $1.3774 \%$ & $0.9500 \%$ & $1.9503 \%$ & $1.1732 \%$ & $1.3998 \%$ & $0.9341 \%$ \\
\hline Vinci & $0.5783 \%$ & $1.2596 \%$ & $1.1046 \%$ & $1.1772 \%$ & $1.0459 \%$ & $0.5000 \%$ \\
\hline XP & $10.2100 \%$ & $-0.4354 \%$ & $2.0337 \%$ & $10.0282 \%$ & $7.8339 \%$ & $-0.4345 \%$ \\
\hline
\end{tabular}


INDEPENDENT JOURNAL OF MANAGEMENT \& PRODUCTION (IJM\&P)

http://www.ijmp.jor.br

v. 9, n. 4, October - December 2018

ISSN: 2236-269X

DOI: 10.14807/ijmp.v9i4.822

Table 4: Monthly profitability of the analyzed funds from April/2016 to November/2015

\begin{tabular}{|c|c|c|c|c|c|c|}
\hline Fund & Apr/2016 & Mar/2016 & Feb/2016 & Jan/2016 & Dec/2015 & Nov/2015 \\
\hline Apex & $2.1168 \%$ & $-1.3329 \%$ & $0.3951 \%$ & $1.8797 \%$ & $1.5338 \%$ & $0.2011 \%$ \\
\hline BB & $1.2722 \%$ & $1.1176 \%$ & $1.3348 \%$ & $-1.1242 \%$ & $1.3668 \%$ & $0.4956 \%$ \\
\hline Bradesco & $1.2754 \%$ & $7.4744 \%$ & $1.2197 \%$ & $-6.0286 \%$ & $0.2868 \%$ & $1.3298 \%$ \\
\hline Brasil & $1.1992 \%$ & $1.2987 \%$ & $0.9428 \%$ & $1.0874 \%$ & $1.2548 \%$ & $1.1732 \%$ \\
\hline BTG & $2.6857 \%$ & $1.2936 \%$ & $1.0461 \%$ & $1.7799 \%$ & $2.2194 \%$ & $2.1703 \%$ \\
\hline Citifirst & $3.6508 \%$ & $2.2811 \%$ & $-2.2231 \%$ & $-4.6470 \%$ & $1.0403 \%$ & $1.1311 \%$ \\
\hline Fator & $1.7585 \%$ & $-2.4713 \%$ & $0.7527 \%$ & $1.0889 \%$ & $1.0241 \%$ & $2.4807 \%$ \\
\hline Growler & $3.4987 \%$ & $-3.1705 \%$ & $0.7125 \%$ & $3.2053 \%$ & $1.4467 \%$ & $1.9633 \%$ \\
\hline Itaú & $1.3039 \%$ & $1.0111 \%$ & $0.7627 \%$ & $0.8097 \%$ & $1.3421 \%$ & $1.1030 \%$ \\
\hline ARX & $4.6754 \%$ & $1.1493 \%$ & $-0.5810 \%$ & $2.1377 \%$ & $1.1100 \%$ & $0.9539 \%$ \\
\hline Mauá & $3.4908 \%$ & $2.6369 \%$ & $3.5506 \%$ & $4.4494 \%$ & $0.3311 \%$ & $1.4070 \%$ \\
\hline Modal & $2.5710 \%$ & $3.8680 \%$ & $2.6254 \%$ & $1.7054 \%$ & $0.9348 \%$ & $1.5747 \%$ \\
\hline Opp. & $2.8125 \%$ & $-1.1105 \%$ & $0.6671 \%$ & $2.2254 \%$ & $0.1384 \%$ & $2.9156 \%$ \\
\hline Safra & $-3.5950 \%$ & $-3.5889 \%$ & $-0.3646 \%$ & $-5.2632 \%$ & $1.1529 \%$ & $1.2281 \%$ \\
\hline Santander & $2.4534 \%$ & $-0.3597 \%$ & $0.6844 \%$ & $1.8882 \%$ & $1.4719 \%$ & $1.2414 \%$ \\
\hline Sicredi & $2.1589 \%$ & $1.7394 \%$ & $1.2283 \%$ & $1.2331 \%$ & $1.1532 \%$ & $2.0877 \%$ \\
\hline SPX & $3.5209 \%$ & $-3.0719 \%$ & $0.7422 \%$ & $3.2376 \%$ & $1.4781 \%$ & $1.9856 \%$ \\
\hline Sul & $0.6977 \%$ & $1.7639 \%$ & $1.5585 \%$ & $1.2782 \%$ & $1.0155 \%$ & $1.4467 \%$ \\
\hline Vinci & $2.3466 \%$ & $0.6023 \%$ & $1.2800 \%$ & $2.7116 \%$ & $1.9657 \%$ & $0.4994 \%$ \\
\hline XP & $9.1813 \%$ & $14.5330 \%$ & $8.1605 \%$ & $3.0673 \%$ & $0.0843 \%$ & $1.6444 \%$ \\
\hline
\end{tabular}

Table 5: Monthly profitability of the analyzed funds from October/2015 to May/2015

\begin{tabular}{|c|c|c|c|c|c|c|}
\hline Fund & Oct/2016 & Sep/2016 & Aug/2016 & Jul/2016 & Jun/2015 & May/2015 \\
\hline Apex & $-1.2732 \%$ & $2.0125 \%$ & $1.5893 \%$ & $2.5813 \%$ & $1.5965 \%$ & $1.1027 \%$ \\
\hline BB & $3.0969 \%$ & $0.2232 \%$ & $-3.4025 \%$ & $-0.6645 \%$ & $0.7032 \%$ & $1.1254 \%$ \\
\hline Bradesco & $9.3683 \%$ & $-1.9336 \%$ & $-5.2430 \%$ & $2.9121 \%$ & $-0.9744 \%$ & $2.1542 \%$ \\
\hline Brasil & $1.2887 \%$ & $1.2110 \%$ & $0.9611 \%$ & $1.3403 \%$ & $1.2607 \%$ & $1.1091 \%$ \\
\hline BTG & $3.8261 \%$ & $-0.7333 \%$ & $-0.3491 \%$ & $1.2453 \%$ & $1.1454 \%$ & $1.6084 \%$ \\
\hline Citifirst & $1.9259 \%$ & $-0.5159 \%$ & $0.1833 \%$ & $1.5728 \%$ & $0.3813 \%$ & $0.8502 \%$ \\
\hline Fator & $1.5803 \%$ & $1.3771 \%$ & $-0.3067 \%$ & $5.4117 \%$ & $-0.1586 \%$ & $3.8653 \%$ \\
\hline Growler & $0.5355 \%$ & $1.5871 \%$ & $1.7968 \%$ & $5.3355 \%$ & $0.9062 \%$ & $2.7333 \%$ \\
\hline Itaú & $0.4639 \%$ & $1.0328 \%$ & $1.7886 \%$ & $2.1812 \%$ & $1.9556 \%$ & $0.9172 \%$ \\
\hline ARX & $0.5763 \%$ & $0.9744 \%$ & $0.8263 \%$ & $2.1287 \%$ & $0.9564 \%$ & $1.0362 \%$ \\
\hline Mauá & $5.3673 \%$ & $-1.3635 \%$ & $1.1021 \%$ & $1.5465 \%$ & $-1.2051 \%$ & $1.7966 \%$ \\
\hline Modal & $0.5101 \%$ & $2.2703 \%$ & $2.2402 \%$ & $3.2890 \%$ & $0.4634 \%$ & $1.6778 \%$ \\
\hline Opp. & $2.0621 \%$ & $0.3370 \%$ & $-0.6503 \%$ & $2.5401 \%$ & $-0.6160 \%$ & $1.2625 \%$ \\
\hline Safra & $5.1053 \%$ & $7.0716 \%$ & $-0.4286 \%$ & $12.5058 \%$ & $-4.6033 \%$ & $7.3113 \%$ \\
\hline Santander & $0.8248 \%$ & $1.0468 \%$ & $0.2309 \%$ & $3.2277 \%$ & $0.5960 \%$ & $1.5334 \%$ \\
\hline Sicredi & $0.1644 \%$ & $0.8483 \%$ & $1.3271 \%$ & $1.3311 \%$ & $1.1467 \%$ & $0.8148 \%$ \\
\hline SPX & $0.5695 \%$ & $1.6199 \%$ & $1.8278 \%$ & $5.2596 \%$ & $0.9452 \%$ & $2.7303 \%$ \\
\hline Sul & $0.4367 \%$ & $0.2657 \%$ & $1.6652 \%$ & $0.1542 \%$ & $3.1407 \%$ & $2.3524 \%$ \\
\hline Vinci & $2.6148 \%$ & $0.7021 \%$ & $-0.5876 \%$ & $1.8149 \%$ & $0.8368 \%$ & $1.5955 \%$ \\
\hline XP & $6.5832 \%$ & $-0.0993 \%$ & $-6.7784 \%$ & $3.6497 \%$ & $2.7253 \%$ & $-5.9820 \%$ \\
\hline
\end{tabular}




\subsection{DEMATEL Method Implementation}

Initially the DEMATEL method is used to split the set of multimarket investment funds into two groups. The DEMATEL method makes use of the mutual influence between the components of a studied system, being able to classify these components as impacted, if the offered influence of a given component is inferior to the influence received by the others or as impactors, if the offered influence of a given component is superior to the influence received by the others in the analyzed system.

The funds classified as impactors belong to Group A and the funds classified as impacted belong to Group $B$. The degree of influence each fund has over the other should be established so that the DEMATEL method is implemented. A scale from 0 to 8 will be chosen to establish this degree. This article, assumes that an alternative $a_{1}$ is able to exert influence over an alternative $a_{2}$ when $a_{1}$ finds itself on a superior position from $a_{2}$. That is, if the alternative $a_{1}$ has a better performance than alternative $a_{2}$ in a given criterion, then alternative $a_{1}$ is able to exert influence over alternative $a_{2}$.

Therefore, the influence between alternatives will be established under the following principle: the influence exerted by an alternative $a_{1}$ inside a set of 2 or more alternatives is established when the first occupies a best position in the studied criteria. In case it occupies its best position in more than one criterion, the influence exerted will be established by the most important criterion.

Furthermore, the influence received by an alternative $a_{1}$ in the same set of analysis depends on its performance in moments which the other alternatives occupy their best positions in the studied criteria. In order to define the degree of influence between alternatives demanded by the DEMATEL method, the alternatives should be classified in each criterion according to their performances, analyzing their position criterion by criterion starting with the most important criterion and ending with the least important one.

In this article, the analyzed criteria will be the monthly profitability of the 20 multimarket investment funds, with the most recent month being the most important criterion. This order of importance is done successively until the least recent month. 
INDEPENDENT JOURNAL OF MANAGEMENT \& PRODUCTION (IJM\&P)

http://www.ijmp.jor.br

v. 9, n. 4, October - December 2018

ISSN: 2236-269X

DOI: 10.14807/ijmp.v9i4.822

Thus, every time a given alternative reaches a position superior than another one in a given criterion, it will be able to obtain influence over the one in an inferior position. If an alternative has the same position in two criteria, the preference will be given to the degree of influence in the most important criterion.

It is essential to emphasize that if an alternative has a superior position over the others in only 1 criterion, it does not mean that its influence is exerted in a biased way, because this will be compensated with the impact received by the other alternatives. In this way, the influence that an alternative exerts in the system will be given when this alternative finds itself in its best position in the studied criteria. Preference will be given to the most important criterion if the alternative has the same position in more than one criterion.

Therefore, the 20 investment funds were classified in a decreasing order according to the monthly profitability's presented in Tables 6, 7 and 8.

Table 6: Classification of monthly profitability's from April/2017 to September/2016

\begin{tabular}{|c|c|c|c|c|c|c|c|c|}
\hline Rank & Apr/2017 & Mar/2016 & Feb/2017 & Jan/2017 & Dec/2016 & Nov/2016 & Oct/2016 & Sep/2016 \\
\hline 1st & Safra & SPX & Bradesco & XP & Mauá & Safra & Citifirst & BB \\
\hline 2nd & Mauá & Growler & Mauá & ARX & Bradesco & Bradesco & XP & Mauá \\
\hline 3rd & Bradesco & BB & Apex & Mauá & Fator & BB & Apex & Growler \\
\hline 4th & ARX & Citifirst & Safra & Apex & Opp. & SPX & BB & SPX \\
\hline 5th & Itaú & Itaú & Opp. & SPX & Apex & Growler & ARX & BTG \\
\hline 6th & Apex & Vinci & Modal & Growler & ARX & Modal & SPX & ARX \\
\hline 7th & Sul & Modal & Vinci & Santander & Santander & Brasil & Growler & Modal \\
\hline 8th & Citifirst & Sicredi & ARX & Modal & SPX & Fator & Mauá & Santander \\
\hline 9th & BB & Sul & XP & Bradesco & Growler & Sicredi & Santander & Itaú \\
\hline 10th & Brasil & ARX & Santander & Itaú & Modal & Itaú & Opp. & Brasil \\
\hline 11th & BTG & Brasil & Fator & BTG & BB & BTG & Itaú & Vinci \\
\hline 12th & Sicredi & Fator & Citifirst & Citifirst & Vinci & Sul & Sul & Fator \\
\hline 13th & Sant & BTG & Sicredi & Vinci & BTG & Santander & BRG & Sicredi \\
\hline 14th & Vinci & Santander & Itaú & Sul & Brasil & Vinci & Brasil & Apex \\
\hline 15th & Fator & Bradesco & Brasil & Brasil & Itaú & Mauá & Modal & Sul \\
\hline 16th & Opp. & Opp. & BTG & Opp. & Sul & Manager & Sicredi & Bradesco \\
\hline 17th & Modal & Safra & Sul & BB & Sicredi & Apex & Fator & Safra \\
\hline 18th & SPX & Mauá & SPX & Sicredi & XP & Opp. & Vinci & Opp. \\
\hline 19th & Growler & Apex & Growler & Fator & Citifirst & Citifirst & Bradesco & XP \\
\hline 20th & XP & XP & BB & Safra & Safra & XP & Safra & Citifirst \\
\hline
\end{tabular}


INDEPENDENT JOURNAL OF MANAGEMENT \& PRODUCTION (IJM\&P)

http://www.ijmp.jor.br

v. 9, n. 4, October - December 2018

ISSN: 2236-269X

DOI: 10.14807/ijmp.v9i4.822

Table 7: Classification of monthly profitability's from August/2016 to January/2016

\begin{tabular}{|c|c|c|c|c|c|c|c|c|}
\hline Rank & Aug/2016 & Jul/2016 & Jun/2016 & May/2016 & Apr/2016 & Mar/2016 & Feb/2016 & Jan/2016 \\
\hline 1st & Citifirst & XP & XP & Safra & XP & XP & XP & Mauá \\
\hline 2nd & BB & Safra & ARX & Bradesco & ARX & Bradesco & Mauá & SPX \\
\hline 3rd & SPX & Bradesco & Modal & Opp. & Citifirst & Modal & Modal & Growler \\
\hline 4th & Growler & BB & Opp. & Citifirst & SPX & Mauá & Sul & XP \\
\hline 5th & XP & Citifirst & Apex & Growler & Growler & Citifirst & BB & Vinci \\
\hline 6th & Sul & ARX & Fator & SPX & Mauá & Sul & Vinci & Opp. \\
\hline 7th & ARX & Opp. & Itaú & Fator & Opp. & Sicredi & Sicredi & ARX \\
\hline 8th & Fator & Itaú & Sul & Apex & BTG & Brasil & Bradesco & Santander \\
\hline 9th & Brasil & Fator & Brasil & Brasil & Modal & BTG & BTG & Apex \\
\hline 10th & Mauá & Apex & Santander & Sicredi & Santander & ARX & Brasil & BTG \\
\hline 11th & Sicredi & BTG & BB & Santander & Vinci & BB & Itaú & Modal \\
\hline 12th & BTG & Santander & Sicredi & Sul & Sicredi & Itaú & Fator & Sul \\
\hline 13th & Vinci & Modal & Vinci & Modal & Apex & Vinci & SPX & Sicredi \\
\hline 14th & Bradesco & Brasil & Bradesco & BTG & Fator & Santander & Growler & Fator \\
\hline 15th & Itaú & Vinci & Mauá & Vinci & Itaú & Opp. & Santander & Brasil \\
\hline 16th & Santander & Sul & BTG & Itaú & Bradesco & Apex & Opp. & Itaú \\
\hline 17th & Opp. & Sicredi & SPX & Mauá & BB & Fator & Apex & BB \\
\hline 18th & Modal & Mauá & Growler & BB & Brasil & SPX & Safra & Citifirst \\
\hline 19th & Safra & SPX & Citifirst & XP & Sul & Growler & ARX & Safra \\
\hline 20th & Apex & Growler & Safra & ARX & Safra & Safra & Citifirst & Bradesco \\
\hline
\end{tabular}

Table 8: Classification of monthly profitability's from December/2015 to May/2015

\begin{tabular}{|c|c|c|c|c|c|c|c|c|}
\hline Rank & Dec/2015 & Nov/2015 & Oct/2015 & Sep/2015 & Aug/2015 & Jul/2015 & Jun/2015 & May/2015 \\
\hline 1st & BTG & Opp. & Bradesco & Safra & Modal & Safra & Sul & Safra \\
\hline 2nd & Vinci & Fator & XP & Modal & SPX & Fator & XP & Fator \\
\hline 3rd & Apex & BTG & Mauá & Apex & Growler & Growler & Itaú & Growler \\
\hline 4th & SPX & Sicredi & Safra & SPX & Itaú & SPX & Apex & SPX \\
\hline 5th & Santander & SPX & BTG & Growler & Sul & XP & Brasil & Sul \\
\hline 6th & Growler & Growler & BB & Fator & Apex & Modal & Sicredi & Bradesco \\
\hline 7th & BB & XP & Vinci & Brasil & Sicredi & Santander & BTG & Mauá \\
\hline 8th & Itaú & Modal & Opp. & Santander & Mauá & Bradesco & ARX & Modal \\
\hline 9th & Brasil & Sul & Citifirst & Itaú & Brasil & Apex & SPX & BTG \\
\hline 10th & Sicredi & Mauá & Fator & ARX & ARX & Opp. & Growler & Vinci \\
\hline 11th & Safra & Bradesco & Brasil & Sicredi & Santander & Itaú & Vinci & Santander \\
\hline 12th & ARX & Santander & Santander & Vinci & Citifirst & ARX & BB & Opp. \\
\hline 13th & Citifirst & Safra & ARX & Opp. & Fator & Vinci & Santander & BB \\
\hline 14th & Fator & Brasil & SPX & Sul & BTG & Citifirst & Modal & Brasil \\
\hline 15th & Sul & Citifirst & Growler & BB & Safra & Mauá & Citifirst & Apex \\
\hline 16th & Modal & Itaú & Modal & XP & Vinci & Brasil & Fator & ARX \\
\hline 17th & Mauá & ARX & Itaú & Citifirst & Opp. & Sicredi & Opp. & Itaú \\
\hline 18th & Bradesco & Vinci & Sul & BTG & BB & BTG & Bradesco & Citifirst \\
\hline 19th & Opp. & BB & Sicredi & Mauá & Bradesco & Sul & Mauá & Sicredi \\
\hline 20th & XP & Apex & Apex & Bradesco & XP & BB & Safra & XP \\
\hline
\end{tabular}


INDEPENDENT JOURNAL OF MANAGEMENT \& PRODUCTION (IJM\&P)

http://www.ijmp.jor.br

v. 9, n. 4, October - December 2018

ISSN: 2236-269X

DOI: 10.14807/ijmp.v9i4.822

Initially, it is observed that the fund better positioned in the most important criterion (Table 6) takes into account a scale from 0 to 8 to establish a degree of influence between the alternatives. In this manner, the Safra fund has influence 1 over the Mauá fund, degree of influence 2 over the Bradesco funds, degree of influence 3 over the ARX fund, degree of influence 4 over the Itaú fund, degree of influence 5 over the Apex fund, degree of influence 6 over the Sul fund, degree of influence 7 over the Citifirst fund and degree of influence 8 over the other funds.

Nest, the degree of influence of the SPX fund (fund in the best position according to the second most important criterion) should be established in the same way demonstrated previously. After that, the degree of influence of Bradesco fund should be established and so on, until the degree of influence of all the funds is established in Tables 6, 7 and 8. Alternatives do not have influence over the ones in the same position and they do not have influence over the ones in superior positions. After the degree of influence each alternative has over the others is established, a crossed relationship matrix A should be created (Equation 19).

$A=\left[\begin{array}{llllllllllllllllllll}0 & 8 & 0 & 8 & 8 & 8 & 8 & 8 & 8 & 5 & 0 & 3 & 2 & 1 & 7 & 8 & 8 & 8 & 4 & 6 \\ 8 & 0 & 8 & 8 & 4 & 8 & 8 & 2 & 8 & 5 & 1 & 6 & 8 & 8 & 7 & 8 & 3 & 8 & 8 & 8 \\ 2 & 8 & 0 & 8 & 8 & 8 & 8 & 8 & 8 & 7 & 1 & 5 & 4 & 3 & 8 & 8 & 8 & 8 & 6 & 8 \\ 0 & 7 & 8 & 0 & 2 & 8 & 8 & 5 & 0 & 3 & 8 & 8 & 8 & 8 & 8 & 1 & 4 & 0 & 6 & 0 \\ 2 & 6 & 8 & 8 & 0 & 8 & 8 & 5 & 7 & 8 & 8 & 8 & 8 & 8 & 4 & 8 & 3 & 8 & 1 & 8 \\ 2 & 3 & 8 & 8 & 8 & 0 & 8 & 6 & 8 & 4 & 7 & 8 & 8 & 8 & 8 & 8 & 5 & 8 & 8 & 1 \\ 8 & 8 & 8 & 8 & 1 & 8 & 0 & 4 & 8 & 8 & 8 & 6 & 0 & 8 & 8 & 2 & 3 & 7 & 8 & 5 \\ 8 & 1 & 8 & 8 & 8 & 2 & 8 & 0 & 3 & 8 & 8 & 5 & 8 & 8 & 8 & 6 & 0 & 7 & 4 & 8 \\ 1 & 8 & 8 & 2 & 4 & 8 & 8 & 7 & 0 & 5 & 8 & 8 & 8 & 8 & 8 & 3 & 6 & 0 & 8 & 0 \\ 2 & 8 & 7 & 8 & 8 & 8 & 8 & 4 & 8 & 0 & 1 & 6 & 8 & 8 & 5 & 8 & 3 & 8 & 8 & 0 \\ 4 & 8 & 1 & 8 & 8 & 8 & 2 & 8 & 8 & 5 & 0 & 8 & 3 & 8 & 6 & 8 & 7 & 8 & 8 & 8 \\ 5 & 8 & 8 & 8 & 8 & 8 & 8 & 2 & 3 & 8 & 7 & 0 & 8 & 8 & 8 & 6 & 1 & 4 & 8 & 8 \\ 8 & 8 & 8 & 8 & 2 & 8 & 1 & 5 & 8 & 8 & 8 & 7 & 0 & 8 & 8 & 3 & 4 & 8 & 8 & 6 \\ 5 & 8 & 2 & 8 & 8 & 7 & 8 & 8 & 4 & 3 & 1 & 8 & 8 & 0 & 8 & 8 & 8 & 6 & 8 & 8 \\ 0 & 2 & 8 & 4 & 0 & 8 & 8 & 1 & 3 & 7 & 8 & 8 & 8 & 6 & 0 & 5 & 0 & 8 & 0 & 8 \\ 8 & 8 & 7 & 8 & 0 & 8 & 0 & 2 & 8 & 8 & 6 & 4 & 0 & 8 & 8 & 0 & 1 & 5 & 8 & 3 \\ 8 & 2 & 8 & 8 & 8 & 3 & 8 & 1 & 4 & 8 & 8 & 6 & 8 & 8 & 8 & 7 & 0 & 8 & 5 & 8 \\ 3 & 8 & 8 & 4 & 6 & 8 & 8 & 8 & 2 & 7 & 8 & 8 & 8 & 8 & 8 & 5 & 8 & 0 & 8 & 1 \\ 1 & 5 & 8 & 7 & 0 & 8 & 8 & 4 & 6 & 8 & 8 & 8 & 8 & 8 & 3 & 8 & 2 & 8 & 0 & 8 \\ 3 & 8 & 8 & 8 & 8 & 8 & 8 & 5 & 8 & 1 & 2 & 7 & 8 & 8 & 6 & 8 & 4 & 8 & 8 & 0\end{array}\right]$

The position of each fund in the lines and columns of matrix $A$ is given alphabetically according to the data presented on Table 1. Thus, the Apex fund occupies the first line and first column and the XP fund occupies the last line and column. After the crossed relationship matrix $A$ is created, the DEMATEL method's calculations should start. Table 9 presents the results found with the implementation of the DEMATEL method. 
Table 9: The DEMATEL method's results

\begin{tabular}{|c|c|c|c|c|}
\hline Fund & $\mathbf{r}$ & $\mathbf{c}$ & $\mathbf{r + c}$ & $\mathbf{r - c}$ \\
\hline Apex & 4.4967 & 3.2443 & 7.7410 & 1.2524 \\
\hline BB & 5.1709 & 5.1637 & 10.3347 & 0.0072 \\
\hline Bradesco & 5.1773 & 5.4699 & 10.6472 & -0.2926 \\
\hline Brasil & 3.9397 & 5.6967 & 9.6363 & -1.7570 \\
\hline BTG & 5.2302 & 4.0730 & 9.3032 & 1.1571 \\
\hline Citifirst & 5.1852 & 5.9227 & 11.1079 & -0.7375 \\
\hline Fator & 4.8568 & 5.4841 & 10.3409 & -0.6273 \\
\hline Growler & 4.8514 & 3.9472 & 8.7986 & 0.9042 \\
\hline Itaú & 4.5967 & 4.6763 & 9.2730 & -0.0797 \\
\hline ARX & 4.8705 & 4.8561 & 9.7265 & 0.0144 \\
\hline Mauá & 5.1998 & 4.5072 & 9.7071 & 0.6926 \\
\hline Modal & 5.2041 & 5.3959 & 10.6000 & -0.1918 \\
\hline Opp. & 5.1993 & 5.1130 & 10.3123 & 0.0863 \\
\hline Safra & 5.1843 & 5.8062 & 10.9904 & -0.6219 \\
\hline Santander & 3.9499 & 5.6342 & 9.5841 & -1.6844 \\
\hline Sicredi & 4.1672 & 4.8949 & 9.0622 & -0.7277 \\
\hline SPX & 5.1895 & 3.3178 & 8.5072 & 1.8717 \\
\hline Sul & 5.2469 & 5.1848 & 10.4317 & 0.0622 \\
\hline Vinci & 4.9080 & 5.2027 & 10.1107 & -0.2947 \\
\hline XP & 5.2057 & 4.2393 & 9.4450 & 0.9665 \\
\hline
\end{tabular}

After the implementation of the DEMATEL method, the funds should be split into 2 groups: Group A and Group B. The ones classified as impactors, that is, funds that have a positive $r-c$, belong to Group $A$ and the funds classified as impacted belong to Group B. In this way, the Apex, BB, BTG, Growler, ARX, Mauá, Opp., SPX, Sul and XP funds are members of Group A and the Bradesco, Brasil, Citifirst, Fator, Itaú, Modal, Safra, Santander, Sicredi and Vinci funds are members of Group B (Table 10).

Table 10: Funds' division in Groups $A$ and $B$

\begin{tabular}{|c|c|}
\hline Group A & Group B \\
\hline Apex & Bradesco \\
\hline BB & Brasil \\
\hline BTG & Citifirst \\
\hline Growler & Fator \\
\hline ARX & Itaú \\
\hline Mauá & Modal \\
\hline Opp. & Safra \\
\hline SPX & Santander \\
\hline Sul & Sicredi \\
\hline XP & Vinci \\
\hline
\end{tabular}


INDEPENDENT JOURNAL OF MANAGEMENT \& PRODUCTION (IJM\&P)

http://www.ijmp.jor.br

v. 9, n. 4, October - December 2018

ISSN: 2236-269X

DOI: 10.14807/ijmp.v9i4.822

\subsection{WINGS Method Implementation to the Group A}

At this stage, the WINGS method should be applied in Group A's members. For that, the degree of power of each fund in Group A and the degree of mutual influence between its members should be established with the use of the TOPSIS method.

\subsubsection{Establishment of the degree of power to the Group A's members}

The TOPSIS method is applied on the members of Group A after they were selected using the DEMATEL framework, as it was presented on column 1 of Table 10. The TOPSIS method is used in this moment in the decision-making process in order to establish the degree of power that each member of Group A has in Group A, according to the value of the relative proximity attributed to each fund (Table 11). This degree of influence will be used during the implementation of the WINGS method.

Table 11: Degree of Power established by the TOPSIS method

\begin{tabular}{|c|c|}
\hline Degree of Power & 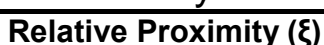 \\
\hline 0 & {$[0=\xi]$} \\
\hline 1 & {$[0<\xi \leq 0.125]$} \\
\hline 2 & {$[0.125<\xi \leq 0.25]$} \\
\hline 3 & {$[0.25<\xi \leq 0.375]$} \\
\hline 4 & {$[0.375<\xi \leq 0.5]$} \\
\hline 5 & {$[0.5<\xi \leq 0.625]$} \\
\hline 6 & {$[0.625<\xi \leq 0.75]$} \\
\hline 7 & {$[0.75<\xi \leq 0.875]$} \\
\hline 8 & {$[0.875<\xi \leq 1]$} \\
\hline
\end{tabular}

The degree of power consists of analyzing the performance of the investment funds reached throughout the studied period, comparing the fund with the best performance in each criterion with all the other funds and comparing the fund with the worst performance in each criterion with all the other funds. Based on these grounds, the TOPSIS method will classify the funds, the best fund will be the one closest to the best performance in every criteria, at the same time it will be the one that distances itself from the worst performance in every criteria.

The TOPSIS method will be applied at this stage considering the funds members of Group A as alternatives and all the months analyzed in the period as criteria. These data are available in Tables 2, 3, 4 and 5. Table 12 presents the results of the TOPSIS method applied in the funds belonging to Group $A$. 
Table 12: The TOPSIS method's results

\begin{tabular}{|c|c|c|c|}
\hline Rank & Fund & Relative Proximity & Degree of Power \\
\hline 1st & SPX & 0.5282 & 5 \\
\hline 2nd & Growler & 0.5255 & 5 \\
\hline 3rd & Mauá & 0.5010 & 5 \\
\hline 4th & BB & 0.5005 & 5 \\
\hline 5th & ARX & 0.4981 & 4 \\
\hline 6th & Sul & 0.4946 & 4 \\
\hline 7th & Apex & 0.4826 & 4 \\
\hline 8th & XP & 0.4796 & 4 \\
\hline 9th & BTG & 0.4761 & 4 \\
\hline 10th & Opp. & 0.4497 & 4 \\
\hline
\end{tabular}

\subsubsection{Establishment of the Degree of Mutual Influence Between Group A's Members}

Besides establishing the degree of power of each alternative in the studied group, the WINGS method also requires the degree of mutual influence between the alternatives. This degree will be established according to the performance of Group A's members in the following criteria: cumulative rate from May/2016 to April/2017 $\left(C_{1}\right)$, volatility from May/2016 to April/2017 ( $\left.C_{2}\right)$, cumulative rate from May/2015 to April/2016 ( $\left.\mathrm{C}_{3}\right)$ and volatility from May/2015 to April/2016 (C4). It is important to emphasize that the profitability's' standard deviation was calculated in order to obtain the volatility in the given period.

This paper takes into account that in order to split a group into two subgroups, a degree of mutual influence between the funds should be established in the same way it is done with the DEMATEL framework. Nevertheless, now other criteria will be analyzed to establish this degree of influence. To establish a degree of influence in the DEMATEL method, months were used as criteria, whereas the performance in two cumulative periods among the months are now used as criteria to split 1 group into 2 subgroups.

The criteria used to establish a degree of mutual influence can be calculated according to the data presented in Tables 2, 3, 4 and 5. The order of importance of the criteria used to obtain the degree of mutual influence is given in decreasing order following the sequence they are mentioned above. Table 13 presents the classification of performances of Group A's members in the 4 criteria mentioned above. 
DOI: 10.14807/ijmp.v9i4.822

Table 13: Position of Group A's members in criteria C1, C2, C3 and C4

\begin{tabular}{|c|c|c|c|c|}
\hline Rank & C1 & C2 & C3 & C4 \\
\hline 1st & XP & Sul & XP & Sul \\
\hline 2nd & BB & BTG & Mauá & BTG \\
\hline 3rd & ARX & SPX & SPX & ARX \\
\hline 4th & Mauá & Growler & Growler & Apex \\
\hline 5th & SPX & Opp. & BTG & Opp. \\
\hline 6th & Growler & Apex & ARX & BB \\
\hline 7th & Apex & Mauá & Sul & SPX \\
\hline 8th & Opp. & ARX & Opp. & Growler \\
\hline 9th & Sul & BB & Apex & Mauá \\
\hline 10th & BTG & XP & BB & XP \\
\hline
\end{tabular}

After the performance classification of Group A's members in criterias $C_{1}, C_{2}$, $\mathrm{C}_{3}$ and $\mathrm{C}_{4}$ is known, the degree of mutual influence between the members of Group A should be established using the same procedure in the DEMATEL method, that is, initially, the degree of influence the XP fund exert over the others is established and so on and so forth, as it was explained previously. method.

\subsubsection{WINGS Method Application to the Group A}

After the degree of power of Group A's members and the degree of mutual influence between the funds in Group $A$ is known by the criteria $C_{1}, C_{2}, C_{3}$ and $C_{4}, a$ force-influence matrix $D$ should be built to initiate the implementation of the WINGS method. Equation 20 presents the force-influence matrix D of Group A's members.

$D=\left[\begin{array}{llllllllll}4 & 2 & 0 & 4 & 0 & 5 & 1 & 3 & 0 & 6 \\ 5 & 5 & 8 & 4 & 1 & 2 & 6 & 3 & 7 & 0 \\ 4 & 7 & 4 & 2 & 6 & 5 & 3 & 1 & 0 & 8 \\ 2 & 5 & 0 & 5 & 4 & 3 & 1 & 0 & 0 & 6 \\ 4 & 0 & 7 & 3 & 4 & 1 & 5 & 2 & 6 & 0 \\ 7 & 8 & 3 & 2 & 4 & 5 & 6 & 1 & 5 & 0 \\ 1 & 4 & 0 & 0 & 3 & 2 & 4 & 0 & 0 & 5 \\ 3 & 6 & 0 & 1 & 5 & 4 & 2 & 5 & 0 & 7 \\ 5 & 8 & 1 & 3 & 7 & 6 & 4 & 2 & 4 & 8 \\ 6 & 1 & 8 & 5 & 2 & 3 & 7 & 4 & 8 & 4\end{array}\right]$

The position of each fund in the lines and columns of the force-influence matrix $\mathrm{D}$ is given alphabetically according to the data presented in the first column of Table 9. Thus, the Apex fund occupies this matrix's first line and first column and the Sul fund occupies this matrix's last line and column. Table 14 presents the WINGS method's results. 
Table 14: The WINGS method's results

\begin{tabular}{|c|c|c|c|c|}
\hline Fund & $\mathbf{r}$ & $\mathbf{c}$ & $\mathbf{r + c}$ & $\mathbf{r - c}$ \\
\hline Apex & 0.0788 & 0.1294 & 0.2082 & -0.0506 \\
\hline BB & 0.1288 & 0.1440 & 0.2728 & -0.0152 \\
\hline BTG & 0.1264 & 0.0988 & 0.2252 & 0.0276 \\
\hline Growler & 0.0821 & 0.0916 & 0.1737 & -0.0096 \\
\hline ARX & 0.1003 & 0.1123 & 0.2126 & -0.0121 \\
\hline Mauá & 0.1286 & 0.1130 & 0.2416 & 0.0156 \\
\hline Opp. & 0.0599 & 0.1235 & 0.1834 & -0.0636 \\
\hline SPX & 0.1043 & 0.0661 & 0.1703 & 0.0382 \\
\hline Sul & 0.1516 & 0.0955 & 0.2472 & 0.0561 \\
\hline XP & 0.1509 & 0.1374 & 0.2883 & 0.0135 \\
\hline
\end{tabular}

After the implementation of the WINGS method, the funds should be split into 2 subgroups: $A_{1}$ and $A_{2}$. The ones classified as impactors, that is, funds that have a positive $r-c$, will belong to Subgroup $A_{1}$ and the funds classified as impacted will belong to Subgroup $A_{2}$. Therefore, the BTG, Mauá, SPX, Sul and XP funds are members of Subgroup $A_{1}$ and the Apex, BB, Growler, ARX and Opp. funds are members of Subgroup $A_{2}$ (Table 15).

Table 15: Subgroups A1 and A2

\begin{tabular}{|c|c|}
\hline Subgroup A1 & Subgroup A2 \\
\hline BTG & Apex \\
\hline Mauá & BB \\
\hline SPX & Gowler \\
\hline Sul & ARX \\
\hline XP & Opp. \\
\hline
\end{tabular}

\subsection{WINGS Method Implementation to the Group B}

As it was done previously with the funds that belong to Group A, at this point, the WINGS method should be applied to the funds belonging to Group $B$ after defining the degree of power with the implementation of the TOPSIS method and establishing a degree of mutual influence between the funds through their positions in the criteria $\mathrm{C}_{1}, \mathrm{C}_{2}, \mathrm{C}_{3}$ and $\mathrm{C}_{4}$.

\subsubsection{Establishment of the degree of power to the Group B's members}

The funds that belong to Group B are presented in the second column of Table 10. The TOPSIS method should be applied to these funds in order to establish the degree of power each one has in Group B. The implementation of the TOPSIS method will evaluated the performance of this group's funds in the months from May/2015 to April/2017 (Tables 2, 3, 4 and 5), that is, these months are the criteria. Table 16 presents the results of the TOPSIS method applied to the Group B's funds, 
INDEPENDENT JOURNAL OF MANAGEMENT \& PRODUCTION (IJM\&P)

http://www.ijmp.jor.br

v. 9, n. 4, October - December 2018

ISSN: 2236-269X

DOI: 10.14807/ijmp.v9i4.822

as well as the degree of power each one has in the group, established according to Table 11.

Table 16: Results of the TOPSIS method in Group B's members

\begin{tabular}{|c|c|c|c|}
\hline Rank & Fund & Relative Proximity & Degree of Power \\
\hline 1st & Modal & 0.5546 & 5 \\
\hline 2nd & Itaú & 0.5218 & 5 \\
\hline 3rd & Brasil & 0.5104 & 5 \\
\hline 4th & Sicredi & 0.5083 & 5 \\
\hline 5th & Santander & 0.5068 & 5 \\
\hline 6th & Vinci & 0.5033 & 5 \\
\hline 7th & Bradesco & 0.4992 & 4 \\
\hline 8th & Fator & 0.4970 & 4 \\
\hline 9th & Citifirst & 0.4595 & 4 \\
\hline 10th & Safra & 0.4446 & 4 \\
\hline
\end{tabular}

\subsubsection{Establishment of the degree of mutual influence between Group B's members}

As it was done previously with the funds that belong to Group A, at this point, the degree of mutual influence between the Group B's members should be established through the position of each one in the criteria $C_{1}, C_{2}, C_{3}$ and $C_{4}$. Table 17 presents the classification of the performance of Group B's members in these criteria.

Table 17: Position of Group B's members in criteria C1, C2, C3 and C4

\begin{tabular}{|c|c|c|c|c|}
\hline Rank & C1 & C2 & C3 & C4 \\
\hline 1st & Citifirst & Brasil & Modal & Brasil \\
\hline 2nd & Bradesco & Sicredi & Vinci & Itaú \\
\hline 3rd & Itaú & Itaú & Fator & Sicredi \\
\hline 4th & Modal & Vinci & Sicredi & Santander \\
\hline 5th & Santander & Santander & Safra & Vinci \\
\hline 6th & Fator & Fator & Santander & Modal \\
\hline 7th & Brasil & Modal & Itaú & Fator \\
\hline 8th & Vinci & Bradesco & Brasil & Citifirst \\
\hline 9th & Sicredi & Safra & Bradesco & Bradesco \\
\hline 10th & Safra & Citifirst & Citifirst & Safra \\
\hline
\end{tabular}

Now, the degree of mutual influence between Group B's members should be established according to these funds' positions in Table 17 in the same way it was done in this paper's sections 3.1. and 3.2.2. In this way, initially, the degree of mutual influence of Citifirst fund over the others inside Group B and so on. 
INDEPENDENT JOURNAL OF MANAGEMENT \& PRODUCTION (IJM\&P)

http://www.ijmp.jor.br

v. 9, n. 4, October - December 2018

ISSN: 2236-269X

DOI: 10.14807/ijmp.v9i4.822

\subsubsection{WINGS method application to the Group B's members}

After the degree of power of each Group B's funds and the degree of mutual influence between the funds in Group B is known, a force-influence matrix D should be built to initiate the implementation of the WINGS method. Equation 21 presents the force-influence matrix D between Group B's members.

$D=\left[\begin{array}{llllllllll}4 & 5 & 0 & 4 & 1 & 2 & 8 & 3 & 7 & 6 \\ 7 & 5 & 8 & 5 & 2 & 6 & 8 & 4 & 1 & 3 \\ 1 & 6 & 4 & 5 & 2 & 3 & 8 & 4 & 8 & 7 \\ 6 & 5 & 7 & 4 & 4 & 0 & 2 & 3 & 1 & 0 \\ 7 & 0 & 6 & 5 & 5 & 4 & 8 & 2 & 1 & 3 \\ 8 & 7 & 8 & 2 & 6 & 5 & 4 & 5 & 3 & 1 \\ 4 & 3 & 5 & 0 & 2 & 0 & 4 & 1 & 0 & 0 \\ 5 & 0 & 4 & 3 & 0 & 2 & 6 & 5 & 0 & 1 \\ 6 & 0 & 8 & 4 & 1 & 5 & 7 & 3 & 5 & 2 \\ 7 & 6 & 8 & 1 & 5 & 0 & 3 & 4 & 2 & 5\end{array}\right]$

The position of each fund in the lines and columns of the force-influence matrix $D$ is given alphabetically according to the data presented in the second column of Table 10. Thus, the Bradesco fund occupies this matrix's first line and first column and the Vinci fund occupies this matrix's last line and column. Table 18 presents the WINGS method's results.

Table 18: The WINGS method's results

\begin{tabular}{|c|c|c|c|c|}
\hline Fund & $\mathbf{r}$ & $\mathbf{c}$ & $\mathbf{r + c}$ & $\mathbf{r - c}$ \\
\hline Bradesco & 0.1143 & 0.1567 & 0.2711 & -0.0424 \\
\hline Brasil & 0.1408 & 0.1070 & 0.2479 & 0.0338 \\
\hline Citifirst & 0.1377 & 0.1653 & 0.3030 & -0.0277 \\
\hline Fator & 0.0923 & 0.0949 & 0.1872 & -0.0025 \\
\hline Itaú & 0.1174 & 0.0797 & 0.1971 & 0.0377 \\
\hline Modal & 0.1416 & 0.0771 & 0.2187 & 0.0645 \\
\hline Safra & 0.0547 & 0.1675 & 0.2221 & -0.1128 \\
\hline Santander & 0.0738 & 0.0974 & 0.1713 & -0.0236 \\
\hline Sicredi & 0.1176 & 0.0816 & 0.1993 & 0.0360 \\
\hline Vinci & 0.1184 & 0.0814 & 0.1998 & 0.0371 \\
\hline
\end{tabular}

After the implementation of the WINGS method, the funds should be split into 2 subgroups: $B_{1}$ and $B_{2}$. The ones classified as impactors, that is, funds that have a positive $r-c$, will belong to Subgroup $B_{1}$ and the funds classified as impacted will belong to Subgroup $B_{2}$. Therefore, the Brasil, Itaú, Modal, Sicredi and Vinci funds are members of Subgroup $B_{1}$ and the Bradesco, Citifirst, Fator, Safra and Santander funds are members of Subgroup $B_{2}$ (Table 19). 
Table 19 - Subgroups B1 and B2

\begin{tabular}{|c|c|}
\hline Subgroup B1 & Subgroup B2 \\
\hline Brasil & Bradesco \\
\hline Itaú & Citifirst \\
\hline Modal & Fator \\
\hline Sicredi & Safra \\
\hline Vinci & Santander \\
\hline
\end{tabular}

\section{DATA ANALYSIS}

This data analysis seeks to investigate 2 evaluation points. The first one analyzes the cumulative rate in the studied period and forms 4 levels of classification in order to see the funds with higher profitability throughout the period that were best evaluated by the methodology. The second one seeks to present 4 ways prioritizing the decision inside the best subgroup, that is, Subgroup $A_{1}$. These 4 ways of prioritizing the decision are established through the results of the WINGS method, they are 4 ordinations done based on the foundations of power and mutual influence of this method's framework. This allows a support among investors' decision with different points of view.

\subsection{Comparison between the Subgroups Established by the Methodology and the Subgroups Established by the Cumulative Rate}

Since the multimarket investment funds are already split into 4 subgroups, that is, in 4 levels of classification, subgroups: $A_{1}, A_{2}, B_{1}$ and $B_{2}$; at this point, $a$ comparison of this classification with the classification done by the funds' cumulative rate throughout the studied period should be made.

Based on the results obtained with implementation of the methodology presented in this paper, each subgroup has 5 funds in its level of classification. Therefore, the 20 funds will be divided into 4 groups ( $A, B$ C and D) with 5 funds in each one of them according to the classification in decreasing order established by the calculation of the funds' cumulative rate in the studied period. This calculation will be made with the data of Tables 2, 3, 4 and 5 . Table 20 presents the 4 subgroups formed by the methodology proposed here. 
DOI: 10.14807/ijmp.v9i4.822

Table 20: Subgroups A1, A2, B1 and B2

\begin{tabular}{|c|c|c|c|}
\hline Subgroup A1 & Subgroup A2 & Subgroup B1 & Subgroup B2 \\
\hline BTG & Apex & Brasil & Bradesco \\
\hline Mauá & BB & Itaú & Citifirst \\
\hline SPX & Gowler & Modal & Fator \\
\hline Sul & ARX & Sicredi & Safra \\
\hline XP & Opp. & Vinci & Santander \\
\hline
\end{tabular}

Now, the funds will be split into 4 groups: Group A, Group B, Group C and Group D according to the calculation of the cumulative rate from May/2015 to April/2017. The 5 funds with higher cumulative profitability in this period will belong to Group A and so on until the 4 Groups are formed (Table 21).

Table 21: Groups A, B, C and D

\begin{tabular}{|c|c|c|c|}
\hline Group A & Group B & Group C & Group D \\
\hline XP & ARX & BTG & Vinci \\
\hline Mauá & Bradesco & Itaú & Opp. \\
\hline Modal & BB & Santander & Brasil \\
\hline SPX & Fator & Apex & Sicredi \\
\hline Growler & Citifirst & Sul & Safra \\
\hline
\end{tabular}

Initially, it is important to emphasize that the proposed methodology used indicators in its implementation, such as, volatility and cumulative rate in two of the studied periods established in the total studied period (the last 12 months and the 12 second-to-last months), which is significantly different from using the cumulative rate of the entire period. The main motivation for this comparison is to see if the funds that obtained higher profitability in the entire period, that is, the funds which enabled higher returns to their investors, are the ones best classified in the proposed methodology.

It is also important to highlight that the way the mutual influence between funds was established in 3 parts of the methodology's implementation does not correspond to the way the cumulative rate is calculated. Therefore, the proposed methodology intends to evaluate the funds' behavior according to the precepts following its implementation.

The calculation of the cumulative rate will classify the funds according to the best performance throughout the period, it does not matter the path outlined by each fund to reach its final return in this period. A fund that at some point obtains a very high profitability in order to be taken to a better position compared to the others, but that in other moments obtained a bad profitability if compared to others, is 
INDEPENDENT JOURNAL OF MANAGEMENT \& PRODUCTION (IJM\&P)

http://www.ijmp.jor.br

v. 9, n. 4, October - December 2018

ISSN: 2236-269X

DOI: 10.14807/ijmp.v9i4.822

considered the best alternative, because the calculation of the cumulative rate in influenced by spikes.

The proposed methodology intends to evaluate a fund's profitability's in comparison to the others and many times without taking into account how a fund is superior to the other, only if it is superior or not, except for the moment when the degree of power is generated during the implementation of the TOPSIS method.

The motivation behind such analysis is that there is no guarantee that moments with high profitability's will repeat in other moments, but there is a behavior that many times is superior and demonstrated a better management and expertise. For that, the behavior of the funds' profitability's should be analyzed according to this paper's Section 3, based on the assumption that the best funds for future investments are the ones that behaved better in comparison to the others in each studied point and did not obtain high profitability in the entire period.

Comparing Tables 20 and 21, it is noted that the XP, Mauá and SPX funds find themselves in the best level of classification in both tables, that is, these funds behaved better in comparison to the others in the studied points and they have also the higher profitability in this period.

The BTG and Sul funds find themselves in the best level of classification in Table 20 while they are classified as Group C in Table 21. That happens because, although they did not obtain the best profitability's in the studied period, they behaved better compared to the others in the period. That is, they are the best options for a future investment that the Modal (Group A in Table 21 and Subgroup $B_{1}$ in Table 20) and Growler funds (Group A in Table 21 and Subgroup $A_{2}$ in Table 20).

\subsection{Prioritization of funds in Subgroup A1}

With the implementation of the WINGS method it is possible to obtain the 4 classifications for the analyzed funds in order to create different ways of prioritizing the decision inside Subgroup $A_{1}$. The results of Group A's members generated by the WINGS method (Table 14) present the following interpretation: the values in column $r$ represent the impact of each alternative on the others it does not matter how much impact it receives or how much it impacts the others.

The results of column $r+c$ represent the total involvement of a funds in the analyzed subgroup, because this result is the sum of the offered with the received 
INDEPENDENT JOURNAL OF MANAGEMENT \& PRODUCTION (IJM\&P)

http://www.ijmp.jor.br

v. 9, n. 4, October - December 2018

ISSN: 2236-269X

DOI: 10.14807/ijmp.v9i4.822

impact. The results of column $r$-c classify the funds as impacted or impactors. The impacted have a negative result of $r$ - $c$, since they represent funds that obtained inferior offered impact to the impact received in this analyzed subgroup.

The impactors have a negative result of $r-c$, since they represent funds that obtained superior offered impact to the impact received in this analyzed subgroup. Thus, the 4 classifications were formed with the funds belonging to Subgroup $A_{1}$ (Table 22) with the results of the WINGS method (Table 14).

Table 22: Prioritization of the funds members of Subgroup A1

\begin{tabular}{|c|c|c|c|c|}
\hline Rank & r & c & r+c & r-c \\
\hline 1st & Sul & SPX & XP & Sul \\
\hline 2nd & XP & Sul & Sul & SPX \\
\hline 3rd & Mauá & BTG & Mauá & BTG \\
\hline 4th & BTG & Mauá & BTG & Mauá \\
\hline 5th & SPX & XP & SPX & XP \\
\hline
\end{tabular}

The classification formed by column $r$ was established in decreasing order. In this classification, the best fund is the one that impacts the others in the analyzed points it does not matter how much impact it receives. The way that this prioritization was established seeks to assist an investor who prioritizes how a given fund is found more superior than the others in the analyzed points, without taking into account how this funds behaved when the others obtains a better performance when compared to it.

The classification formed by column $c$ was established in increasing order. In this classification, the best fund is the one that receives less impact from the others it does not matter how much it is able to impact the others. In other words, it is the fund the better defends itself. The way that this prioritization was established seeks to assist an investor who prioritizes how a given fund behaves when the others find themselves in their best positions.

The classification formed by column $r+c$ was established in decreasing order. In this classification, the best fund is the one that has a bigger involvement inside the system, because its result is the sum of the offered impact with the received impact.

The way that this prioritization was established seeks to assist an investor who prioritizes the alternative that impacts the others, that is, how a fund is found in the best positions of the studied points compared to the others summed in some 
INDEPENDENT JOURNAL OF MANAGEMENT \& PRODUCTION (IJM\&P)

http://www.ijmp.jor.br

v. 9, n. 4, October - December 2018

ISSN: 2236-269X

DOI: 10.14807/ijmp.v9i4.822

level of risk. This level of risk is used in this classification because it takes into consideration the received impact by an alternative in the analyzed subgroup.

The classification formed by column $r$-c was established in decreasing order. This classification is formed by the difference between the offered impact and the received impact by an alternative in the analyzed subgroup, that is, is it the offered impact discounted from the received impact. It can be said that this classification is more conservative than the others, because it discounts from the offered impact the received impact by a fund in the analyzed subgroup.

\section{CONCLUSION}

This paper sought to develop a methodology able to classify the 20 analyzed multimarket investment funds in 4 performance levels, the subgroups $A_{1}, A_{2}, B_{1}$ and $B_{2}$. For that, DEMATEL, TOPSIS and WINGS methods were used. It is essential to reinforce that the classification obtained by the proposed methodology is not influenced by spikes as some performance indicators are, like the cumulative rate, according to the data analysis.

With the comparison between the established methodology and the classification established by the cumulative rate of the entire period, it was possible to notice how two forms of analysis diverge in some points since they evaluate the performance differently as well as it was possible to notice that some funds were well classified in both methodologies. This was important to point out that the fund with the highest cumulative profitability in a given period may not be the one with the best performance classification.

The data analysis presents 4 ways of prioritizing the decision between the best classified funds, because the results generated by the WINGS method take different paths because of the way the methodology is founded. This paper is intended to be used for the classification of other sets of investment funds in order to facilitate the reading of the funds' performance behavior when analyzed jointly. The combined implementation of the DEMATEL, TOPSIS and WINGS methods may also be applied to other sets of financial products, in which a classification of these products on different performance levels is required. 
INDEPENDENT JOURNAL OF MANAGEMENT \& PRODUCTION (IJM\&P)

http://www.ijmp.jor.br

v. 9, n. 4, October - December 2018

ISSN: 2236-269X

DOI: 10.14807/ijmp.v9i4.822

\section{REFERENCES}

ANBIMA. (2017)

http://www.anbima.com.br/data/files/B4/B2/98/EF/642085106351AF7569A80AC2/Ca rtilha_da_Nova_Classificacao_de_Fundos_1_.pdf. Access: 20 July 2017.

CALDEIRA, J. F.; MOURA, G. V.; SANTOS, A. A. P.; TESSARI, C. (2014) Seleção de carteiras com modelos fatoriais heterocedásticos: aplicação para fundos multimercados. Revista de Administração Mackenzie, v. 15, n. 2, p. 127-161.

DUARTE JUNIOR, A. M.; MEDEIROS, L. C. B. (2016) Investing in private equity in Brazil. Brazilian Business Review, v. 15, n. 3, p. 51-84.

ELTON, E. J.; GRUBER, M. J. (1995) Modern portfolio theory and investment analysis, 5 ed. New York: John Wiley \& Sons.

GABUS, A.; FONTELA, E. (1972) World problems, an invitation to further thought within the framework of DEMATEL. Battelle Geneva Research Centre.

GOMES, L. F. A. M.; RANGEL, L. A. D.; SANTOS, G. (2016) An AHP-based asset allocation model. International Journal of Business and Systems Research, v. 10 , n. 1 , p. $78-99$.

HAUGEN, R.A. (1997) Modern investment theory, 4 ed. New Jersey: Prentice-Hall. HWANG, C. L.; YOON, K. (1981) Multiple attribute decision making: methods and applications. Berlin: Springer-Verlag.

INFOMONEY. (2005) http://www.infomoney.com.br/noticias/noticia/412945/hedgefunds-sem-misterios-entenda-que-sao-como-funcionam. Access: 13 June 2017.

LONGARAY, A. A.; ENSSLIN, L.; MACKNESS, J. R. (2014) Multicriteria decision analysis to lead about messes problems: an illustrated case. Independent Journal of Management \& Production, v. 5, n. 3, p. 677-692.

MALAQUIAS, R. F.; EID JUNIOR, W. (2014) Fundos multimercados: desempenho, determinantes do desempenho e efeito moderador. Revista de Administração Mackenzie, v. 15, n. 4, p. 135-163.

MARTINS, A. S. S. (2014) Seleção de fundos de investimentos no Brasil: aplicação do método multicritério TOPSIS. Dissertation (Master in Business Administration). Rio de Janeiro: Ibmec Business School.

MELO, R. A.; MACEDO, M. A. S. (2013) Análise multicriterial do desempenho de longo prazo das carteiras de ações de fundos de investimento multimercado macro no Brasil no período de 2005 a 2010. Revista de Evidenciação Contábil \& Finanças, v. 1, n. 2, p. 69-89.

MELLO, B. B. R. (2014) Classificação de risco setorial com base nos métodos Weighted Influence Non-Linear Gauge System and Analytic Hierarchy Process. Dissertation (Master in Business Administration). Rio de Janeiro: Ibmec Business School.

MESRINEJAD, S.; MORADI, A. (2015) Ranking of investment funds of Tehran Exchange by using TOPSIS method. Journal UMP Social Sciences and Technology Management, v. 3, n. 1, p. 157-164. 
MICHNIK, J. (2013) Weighted influence non-linear gauge system (WINGS) - an analysis method for the system of interrelated components. European Journal of Operational Research, v. 228, n. 3, p. $536-544$.

ROVAI, R. L. (2015) Estratégias de fundos multimercado no Brasil e a influência da taxa de performance no seu desempenho. Revista de Finanças Aplicadas, v. 3, p. 1-30.

TZENG, G.; HUANG, J. (2011) Multiple attribute decision making: methods and applications. Boca Raton: CRC Press.

VARGA, G. (2001) Índice de Sharpe e outros indicadores de performance aplicados a fundos de ações brasileiros. Revista de Administração Contemporânea, v. 3, n. 5 , p. $215-245$. 